Davies, D., B. J. Dilley, A. L. Bond, R. J. Cuthbert, and P. G. Ryan. 2015. Trends and tactics of mouse predation on Tristan Albatross Diomedea dabbenena chicks at Gough Island, South Atlantic Ocean. Avian Conservation and Ecology 10(1): 5. http://dx.doi.org/10.5751/ACE-00738-100105 Copyright $(C) 2015$ by the author(s). Published here under license by the Resilience Alliance.

Research Paper

\title{
Trends and tactics of mouse predation on Tristan Albatross Diomedea dabbenena chicks at Gough Island, South Atlantic Ocean
}

\author{
Delia Davies ${ }^{1}$, Ben J. Dilley ${ }^{1}$, Alexander L. Bond ${ }^{2}$, Richard J. Cuthbert ${ }^{3,4}$ and Peter G. Ryan ${ }^{1}$ \\ ${ }^{1}$ Percy FitzPatrick Institute of Africa Ornithology, DST/NRF Centre of Excellence, University of Cape Town, South Africa, ${ }^{2}$ RSPB \\ Centre for Conservation Science, Royal Society for the Protection of Birds, Sandy, UK, ${ }^{3}$ RSPB Centre for Conservation Science, \\ Royal Society for the Protection of Birds, UK, ${ }^{4}$ Wildlife Conservation Society, Goroka, Papua New Guinea
}

\begin{abstract}
The critically endangered Tristan Albatross Diomedea dabbenena breeds almost exclusively on Gough Island, in the central South Atlantic, where breeding success is much lower than other great albatrosses (Diomedea spp.) worldwide. Most breeding failures occur during the chick-rearing stage, when other great albatrosses suffer few failures. This unusual pattern of breeding failure is assumed to be largely due to predation by introduced house mice Mus musculus, but there have been few direct observations of mouse attacks. We closely monitored the fates of 20 chicks in the Gonydale study colony (123 chicks in 2014) using motion-activated cameras to determine the causes of chick mortality. Only 5 of 20 chicks survived to fledge, and of the 15 failures, 14 ( $93 \%$ ) were due to mouse predation. One mouse-wounded chick was killed by a Southern Giant Petrel Macronectes giganteus; the rest died outright from their wounds within $3.9 \pm 1.2$ days of the first attack. Despite this high impact, most chicks were attacked by only 1-2 mice at once (maximum 9). The remaining 103 chicks in the study colony were checked less frequently, but the timing of failures was broadly similar to the 20 closely monitored nests, and the presence of mouse wounds on other chicks strongly suggests that mice were responsible for most chick deaths. Breeding success in the Gonydale study colony averages 28\% from 2001 to 2014; far lower than the normal range of breeding success of Diomedea species occurring on islands free from introduced predators. Island-wide breeding success fell below $10 \%$ for the first time in 2014, making it even more urgent to eradicate mice from Gough Island.
\end{abstract}

\section{Tendances et tactiques de prédation par des souris sur les poussins d'Albatros de Tristan Diomedea dabbenena à l'île Gough, océan Atlantique Sud}

RÉSUMÉ. L'Albatros de Tristan Diomedea dabbenena, espèce en danger critique d'extinction, se reproduit presque exclusivement sur l'île Gough dans l'océan Atlantique Sud, où son succès de reproduction est très faible comparativement à celui des autres grands albatros (Diomedea spp.) dans le monde. La majorité des échecs de reproduction surviennent durant l'élevage des oisillons, alors qu'il y a peu d'échecs de ce type chez les autres grands albatros. On pense que cette tendance inhabituelle d'échec de la reproduction est presque exclusivement attribuable à la prédation par la souris commune Mus musculus, espèce introduite, bien qu'il y ait eu peu d'observations directes d'attaques par celle-ci. Nous avons surveillé de près le destin de 20 poussins dans la colonie de Gonydale (123 poussins en 2014 ) au moyen de caméras à détection de mouvement afin de déterminer les causes de mortalité. Seuls 5 des 20 poussins ont survécu jusqu'à l'envol, et des 15 échecs, 14 (93\%) ont été causés par prédation de souris. Un poussin blessé par une souris a été tué par un Pétrel géant Macronectes giganteus; les autres poussins sont à l'évidence morts à la suite de leurs blessures en dedans de 3,9 $\pm 1,2$ jours de la première attaque par les souris. Malgré cet impact très important, la plupart des poussins ont été attaqués par une ou deux souris à la fois seulement (maximum 9). Les 103 autres poussins de la colonie ont été surveillés moins souvent que les 20 poussins suivis de près, mais le moment où survenaient les échecs était en général le même et la présence de blessures causées par des souris sur ces autres poussins laisse croire que les souris étaient responsables de la majorité des mortalités. Le succès de reproduction dans la colonie de Gonydale a été de $28 \%$ en moyenne de 2001 à 2014, soit bien en deçà de l'étendue normale du succès des espèces de Diomedea se reproduisant sur des îles sans prédateurs introduits. Étant donné que le succès de reproduction sur l'ensemble de l'île est passé sous la barre de $10 \%$ pour la première fois en 2014, il devient encore plus urgent d'éradiquer les souris de l'île Gough.

Key Words: eradication; house mouse Mus musculus; predation; Tristan Albatross Diomedea dabbenena

\section{INTRODUCTION}

Many seabirds nest on isolated islands that lack land mammals (Schlaepfer et al. 2002) and consequently they are particularly susceptible to the introduction of mammalian predators such as cats Felis catus and rodents (Atkinson 1985, Croxall et al. 2012). Understanding the effects of introduced mammals on island seabirds are a key issue for conservation biologists (Jones et al.
2008, Le Corre 2008, Jones and Ryan 2010, Medina et al. 2011), and Gough Island, in the central South Atlantic, is a poignant example of an introduced mammal, the house mouse Mus musculus, dramatically affecting the breeding success of a suite of seabirds by preying on their chicks (Cuthbert et al. 2013, 2014).

Gough Island $\left(40^{\circ} 82^{\prime} \mathrm{S}, 9^{\circ} 85^{\prime} \mathrm{W}\right)$ is a UNESCO World Heritage Site and an Important Bird Area (IBA) that hosts significant 
populations of several globally threatened species. Mice are the only introduced mammal on Gough Island. They were brought to the island inadvertently by sealers in the 19th century, and are now ubiquitous throughout the island (Rowe-Rowe and Crafford 1992). Initially, mice were considered to have little impact on the island's birds, being regarded as "probably harmless" (Elliott 1953). However, observations in 2001 led Cuthbert and Hilton (2004) to propose mouse predation as the most probable cause of the unexpectedly high breeding failure of Tristan Albatrosses Diomedea dabbenena and Atlantic Petrels Pterodroma incerta on Gough Island. Subsequent studies confirmed that mice kill the chicks of a wide range of seabirds and also threaten Gough's endemic Bunting Rowettia goughensis (Wanless et al. 2007, Ryan and Cuthbert 2008, Cuthbert et al. 2013).

The population of Tristan Albatrosses breeds almost entirely on Gough Island ( 1800 pairs, Cuthbert et al. 2014), with only 1-2 pairs on Inaccessible Island in the nearby Tristan da Cunha archipelago (Ryan 2005). The population is decreasing by approximately 3\% per year (Wanless et al. 2009, Cuthbert et al. 2014), resulting in the species being listed as Critically Endangered (IUCN 2014). The decline is being driven by the combination of mortality of birds caught on fishing gear at sea and low reproductive output from mouse predation (Wanless et al. 2009). Breeding success is much lower than that of Diomedea spp. albatrosses breeding at predator-free locations (Croxall et al. 1990, Weimerskirch 1992, Tickell 2000, Nel et al. 2003). The majority of breeding failures occur during the chick-rearing period and are assumed to be largely due to predation by introduced house mice (Wanless et al. 2007).

Most evidence of mouse impacts on Tristan Albatrosses comes from chicks showing wounds characteristic of mouse attacks (Wanless et al. 2007). There have been few direct observations of mouse attacks on albatross chicks, because mice are active at night. It is not known how quickly mice kill albatross chicks, or indeed whether they kill the chicks directly or merely weaken them to the point where they fall prey to other predators such as Southern Giant Petrels Macronectes giganteus or Brown Skuas Stercorarius antarcticus (Wanless et al. 2009). Our aim was to assess mouse predation on Tristan Albatross chicks by monitoring and filming a subsample of 20 chicks intensively. We were particularly interested in the proportion of chicks that failed as a result of mouse predation, the mechanisms of mouse predation, and the final outcome of mouse attacks.

\section{METHODS}

Tristan Albatrosses lay eggs in late December-January, with chicks fledging in November. Breeding success of the entire population has been estimated since 2001 by conducting annual counts of incubating adults in late January/February and of large chicks in September (excluding 2002, 2003, 2005, and 2011; Cuthbert et al. 2014). Counts were divided into 8-12 geographical zones across the island. Since 2008 more accurate estimates of breeding success have been obtained from a study colony in the Gonydale Valley ( 150-190 nests per year) where nests and birds were individually marked by researchers who are based on the island year round. Nests were checked approximately every four weeks from laying to fledging (Cuthbert et al. 2014), although in 2014 checks were more frequent (about every 5 days around laying and hatching, and approximately every 2 weeks at other periods). Date of laying was taken as the midpoint between nest checks and date of hatching was taken from when chicks were almost fully out of their eggs or were still wet after hatching (15 nest checks over 79 days). Newly pipped eggs were excluded because the time to emerge varied considerably; two chicks took more than 6 days to fully emerge from their eggs once pipping began.

To gain a better idea of the causes of breeding failure, 28 nests along a path within the Gonydale study colony (Fig. 1) were checked until hatching, with the 20 hatched chicks checked frequently from after hatching (29 March) to midwinter (8 July 2014; 22 checks, $4.7 \pm 4.0$ days between checks). To estimate when chicks hatched, were left alone, or died, we assumed these events occurred at the midpoint between successive checks. On each visit, chicks were inspected for wounds, typical of those inflicted by mice (Wanless et al. 2007, 2009, 2012, Jones and Ryan 2010). The cause of these wounds was confirmed by filming the nests with motion-activated trap cameras (Bushnell Trophy Camera, model 119436) that recorded nocturnal activity with infra-red images. The infra-red flash does not deter predators and these cameras have been used to record Northern Giant Petrels Macronectes halli predating on Wandering Albatross Diomedea exulans chicks on Marion Island (Dilley et al. 2013). Cameras were mounted 30 $\mathrm{cm}$ above the ground on PVC poles, 4-5 $\mathrm{m}$ from the nest, and set on high motion sensitivity to take one image second ${ }^{-1}$ for 3 seconds upon activation. We used external $6 \mathrm{~V} 12$ amp-hour batteries (insulated against the cold weather in plastic tubs) which allowed

Fig. 1. Gough Island showing the location of the long-term Tristan Albatross (Diomedea dabbenena) study colony in the Gonydale Valley. Inset shows the location of all nests in 2014 and the shaded area along the pathway where 28 nests were monitored frequently during the early chick period.

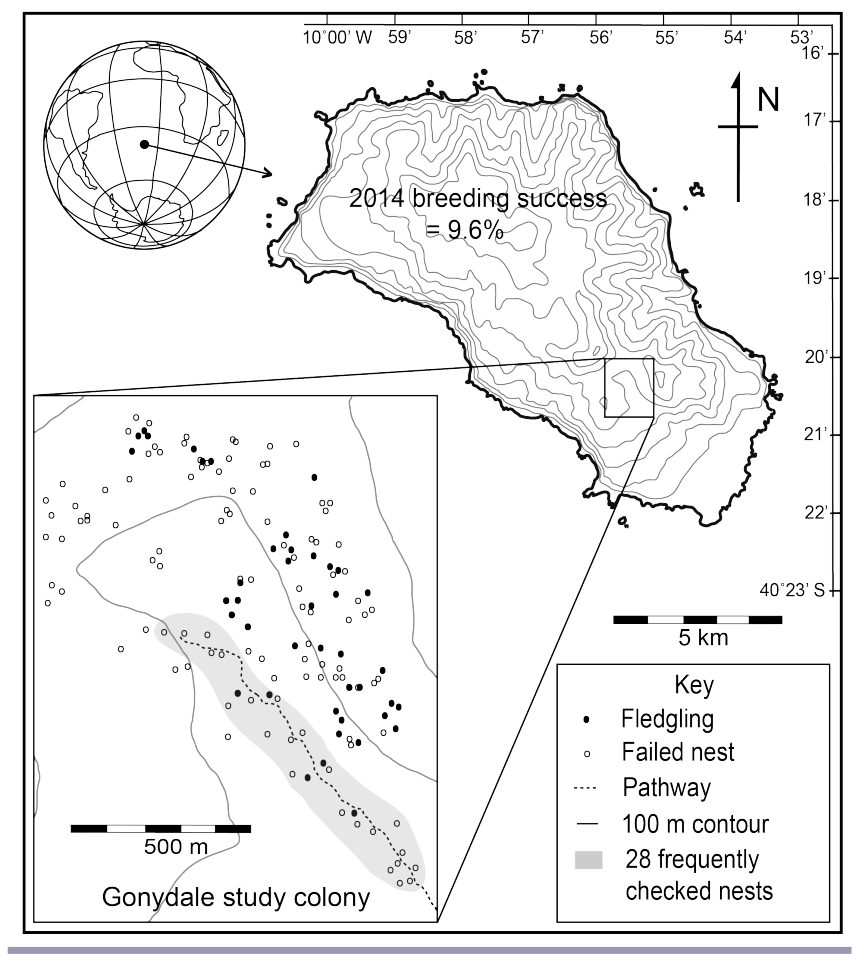


Table 1. Summary of camera effort (61.8 days) monitoring eight Tristan Albatross (Diomedea dabbenena) chicks where six chicks die from mice wounds, one is attacked but recovers (nest 5), and one is not attacked (nest 8). For nest 2, the first attack by mice was not filmed (numbers in parentheses excluded from mean $\pm \mathrm{SD}$ ).

\begin{tabular}{|c|c|c|c|c|c|c|c|c|c|}
\hline Camera nest & 1 & 2 & 3 & 4 & 5 & 6 & 7 & 8 & Mean \pm SD \\
\hline Time monitored (days) & 3.5 & 1.1 & 3.3 & 12.5 & 14.0 & 14.6 & 2.8 & 10.0 & $7.7 \pm 5.6$ \\
\hline Nights when mice attacked & 4 & (3) & 3 & 9 & 2 & 4 & 4 & 0 & $3.7 \pm 2.7$ \\
\hline Number of mice in first attack & 1 & - & 1 & 1 & 1 & 1 & 1 & 0 & $1.0 \pm 0.0$ \\
\hline Maximum number of mice per night & 9 & 2 & 2 & 2 & 1 & 2 & 2 & 0 & $2.0 \pm 1.3$ \\
\hline Average maximum mice per attack night & 5.0 & 1.7 & 1.3 & 1.2 & 1.0 & 1.8 & 2.0 & 0 & $2.0 \pm 1.3$ \\
\hline Days from first attack to death & 3.3 & $(2.7)$ & 4.1 & 2.6 & - & 3.2 & 5.0 & - & $3.5 \pm 0.9$ \\
\hline
\end{tabular}

cameras to run for up to 14 days. By rotating three trap cameras we were able to monitor eight chicks. One chick had a small mouse wound when filming began, but the remaining seven chicks were not wounded. However, chicks were selected based on proximity to other wounded or recently killed chicks because mouse attacks tend to be spatially coherent (Wanless 2007). Detailed behavior of mice attacking wounded chicks at night was recorded by direct observations, and with a GoPro Hero3 video camera using an external red light source.

Analyses of breeding success trends were conducted in the $\mathrm{R}$ statistical environment ( $R$ Core Team 2014) where we used a binomial generalized linear model run in package lme4 (Bates et al. 2014). The statistical power to infer a decrease in breeding success since 2001 was estimated based on the linear regression of reproductive success over time. We also estimated the overall linear population trend using TRIM 3.54 (Pannekoek and van Strien 2001) using counts of incubating adults accounting for serial correlation. As we counted the entire population, we did not adjust for overdispersion. The multiplicative rate of increase $(\lambda)$ is presented \pm S.E. (Cuthbert et al. 2014). All other means are presented \pm S.D.

\section{RESULTS}

\section{Laying, hatching, and incubation period}

In Gonydale, peak egg laying occurred in the last week of December and early January, with $66 \%(82 / 123)$ of eggs laid by 6 January $2014,95 \%$ by 15 January, and the last eggs laid by 31 January 2014. For the 28 closely monitored nests, hatching occurred from 13-28 March 2014 (22 March $2014 \pm 4.6$ days, $n=$ 20). Hatching was more protracted across the whole study colony: 8 March to 6 April 2014 (23 March $2014 \pm 6.3$ days, $n=123$ ). Incubation lasted 73-80 days (75.9 \pm 1.8 days, $n=13)$, similar to other great albatrosses (average 78-79 days; Tickell 2000). For these 13 nests, laying date was accurate to within 3 days and at hatching, the chicks were observed in the advanced stages of hatching $(n=6)$ or were still wet $(n=7)$.

\section{Causes of breeding failure}

Of the 28 frequently monitored nests along the Gonydale path, 8 failed at the egg stage $(29 \%)$, slightly more than the entire Gonydale colony in $2014(17 \%, \mathrm{n}=149)$. Of the 20 chicks that hatched, one small chick disappeared overnight while being brooded, when its nest mound was partly washed away in heavy rains. The other 19 chicks survived the brood-guard phase and were left by their parents $33 \pm 6.8$ days after hatching (range 20-49 days, $n=19)$. Although Wanless et al. (2007) reported wounded chicks in March, when still being brooded, the first wounded chick in 2014 was observed on 1 May, 9 days after the parents had left it on its own. Chicks were first attacked by mice $30 \pm 20.4$ days after being left alone (range 1-70 days, $n=16$ ).

Overall, 16 of 19 (84\%) monitored chicks were attacked by mice, with attacks starting when the chicks were $64 \pm 19$ days old (range 35-102 days, $\mathrm{n}=16$ ). Of these 16 wounded chicks, 2 survived, but $14(88 \%)$ died within $3.9 \pm 1.2$ days (range $2-5$ days) of first being attacked. Of these 14 chicks, six were definitely killed by mice (evidence from cameras; Table 1) and eight died shortly after first showing signs of mouse attacks and were almost certainly killed by mice.

Cameras recorded activity at 8 Tristan Albatross nests for a total of 61.8 days from 1 May to 24 July 2014 (Table 1). Cameras captured a total of 98,283 photos $\left(10,920 \pm 10,115\right.$ photos nest $\left.^{-1}\right)$, with cameras triggered more frequently at nests where chicks were more active because of mouse disturbance. In addition, we recorded a total of 15.0 hours of video footage from 4 nests and 8.0 hours (over 2 nights) of direct observations at 1 nest (Fig. 2).

Fig. 2. A six week old Tristan Albatross (Diomedea dabbenena) chick is attacked by mice despite the parent being present at the nest. This chick died 3.3 days after the first mouse attack.

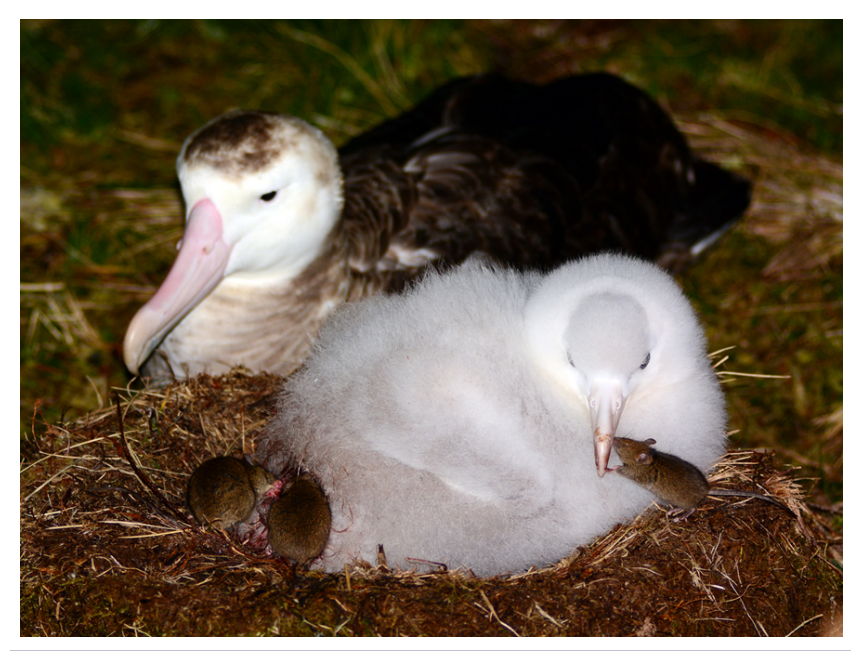


Only one of the filmed chicks was not attacked by mice (camera nest 8 , Table 1). Mice attacked chicks on 29 of the 62 film nights (47\%). All attacks happened at night and the initial attack was always by a single mouse, which repeatedly targeted the same site, usually on the chick's rump, clinging to its down and biting until the skin was penetrated. When displaced by the irritated chick nuzzling its wound, or vigorously shaking its body, the mouse would return to the wound within seconds. Chicks were seldom attacked by more than 1-2 mice at a time, although one chick had up to 9 mice attacking at once (Table 1). The behavior of the mice suggested that this was a well-practiced technique, as they generally climbed directly onto the nest mound and the chick without hesitation.

Chicks would often nuzzle at their open wound and so accumulate blood on their bill, which the mice would then proceed to lick off, often with little or no protest from the injured chick (Fig. 2). This fearless behavior by the mice did not alter if an albatross parent was present at the nest (Fig. 2), or in one case, even brooding its chick. The parents made little, if any, attempt to scare away the mice. In one case a male parent seemingly attempted to protect its five-week old chick, which had a large open wound on the back of its neck. The mice continued to feed on the chick despite the parent's attempt to brood. It was noticeable that mouse attacks increased activity by albatross chicks at night greatly. Without mice present, albatross chicks slept with their heads tucked in, seldom moving at all. By comparison, chicks attacked by mice were unable to sleep, repeatedly trying to chase off the mice, although these efforts became weaker on successive nights.

Of the seven chicks attacked by mice (Table 1), five died outright from their wounds (Fig. 3); one severely wounded chick was killed by an Southern Giant Petrel and one chick recovered from its wounds. One of the chick fatalities (camera nest 6, Table 1) had a relatively small wound compared to other fatally wounded chicks (camera nests, $n=6$ wounded) and had not been fed for 10 days when it eventually died after a period of cold weather. The chick that survived its wounds (camera nest 5, Table 1) was fed by its parent in the 24 hours before its first attack.

Fig. 3. Five of the seven filmed chicks that were attacked by mice died outright from their wounds within $3.9 \pm 1.2$ days of the first attack. Here the parents return to feed their chick to find it has died since their last visit.

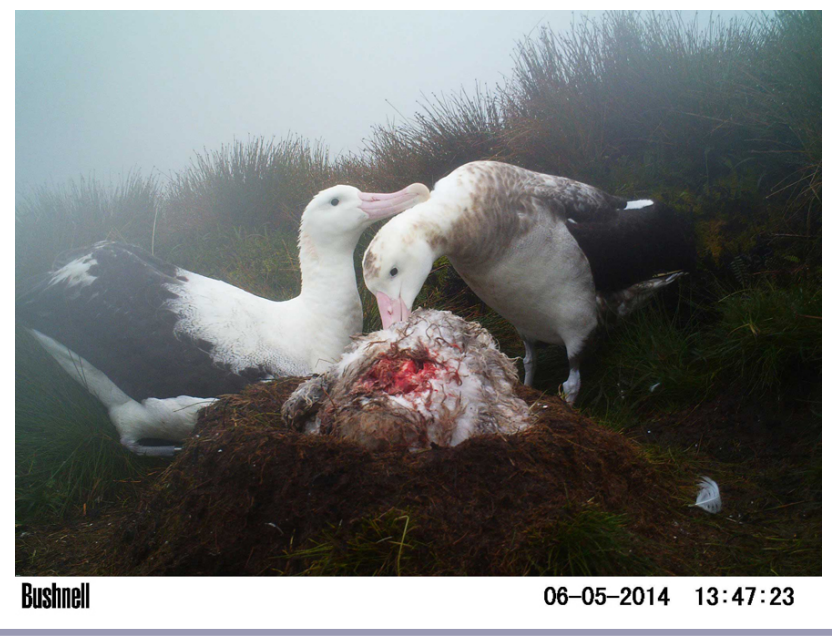

For the entire Gonydale study colony, overall breeding success was $28 \%(n=149$ incubating pairs). Most chick failures $(78 \%)$ occurred in the first three months after hatching (64/82 chick failures, 0.69 chicks per day). Although these nests were checked less frequently, the timing of failures synchronized broadly with the 20 frequently checked nests (Fig. 4) and is consistent with the timing of failures in this colony from 2008 to 2013 (Fig. 5). The most common site for chicks to be wounded was the lower rump $(n=6)$, but mice also targeted the back of the neck (2), top of the head (1), side of the lower mandible (1), the wings (1), or a combination of these locations (1). To view a one minute video of mice attacking a Tristan Albatross chick follow this link: http:// youtu.be/XNxqIYLthus

Fig. 4. The timing of Tristan Albatross (Diomedea dabbenena) chick failures in the Gonydale study colony (103 chicks, black) and for the subsample of frequently checked chicks within the colony ( 20 chicks, grey) in 2014 . Chick mortality represented as a cumulative percentage (y axis). The shaded area represents the time when chicks are first left alone.

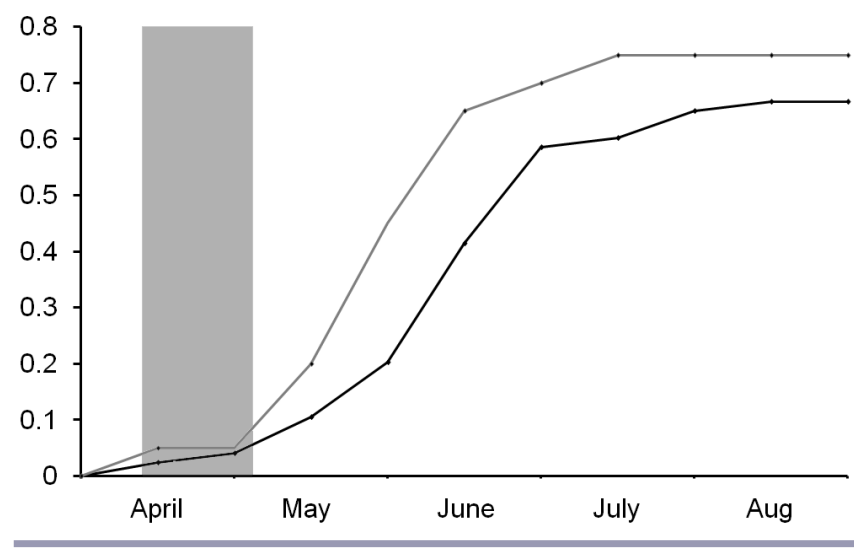

Fig. 5. Tristan Albatross (Diomedea dabbenena) chick failure rate for the years $2008(\mathrm{n}=161$ nests), $2009(\mathrm{n}=172), 2010(\mathrm{n}$ $=175), 2012(\mathrm{n}=192), 2013(\mathrm{n}=201)$, and $2014(\mathrm{n}=149)$ in the Gonydale study colony. No data for 2011. The shaded area represents the time when chicks are first left alone.

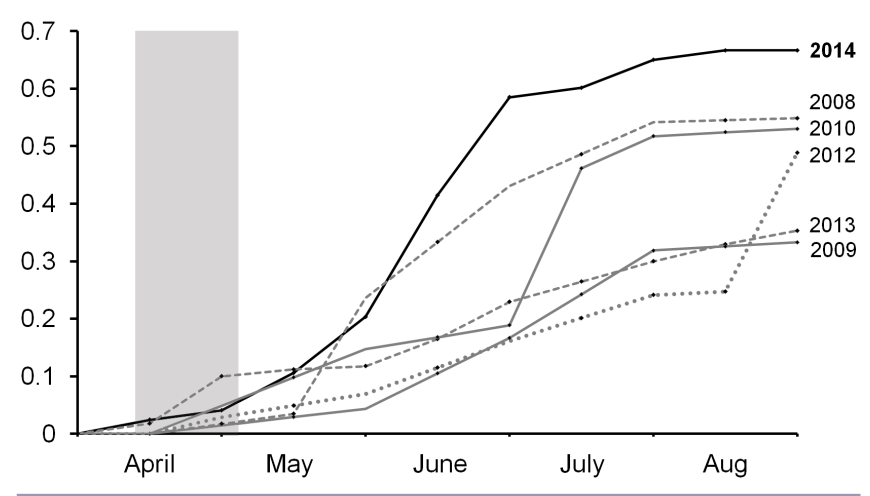




\section{Trends in breeding success and overall population}

The 2014 breeding success for the island population was $9.6 \%$ (n $=1704$ incubating pairs, Table 2), the lowest recorded since annual island-wide counts started in 2001 (Fig. 6). Island-wide breeding success from 2001 to 2014 averaged $28.3 \pm 12.7 \%$. The regression slope $(\beta=-0.025 \pm 0.406)$ was not significantly different from 0 $(\mathrm{t}=-1.1, \mathrm{p}=0.26, \mathrm{n}=10$ years $)$, but the power to detect a significant decrease of this magnitude is small $(\sim 0.26)$ given the relatively short sampling period (Fig. 6). The highest recorded chick production was in 1999, when almost twice as many chicks were counted as in any other year (Wanless et al. 2009). The 163 chicks counted across Gough Island in September 2014 were only $14 \%$ of the 1129 chicks counted in September 1999 (Ryan et al. 2001). The overall population of incubating Tristan Albatrosses is decreasing $\left(\lambda=0.979 \pm 0.002\right.$, Wald $\left.\chi_{1}^{2}=137.07, p<0.01\right)$, and currently numbers around 1650 breeding pairs breeding annually (range from last three censuses: 1451-1745), a decrease of approximately 150 pairs since 2011 (Cuthbert et al. 2014).

Table 2. Island wide Tristan Albatross (Diomedea dabbenena) counts for years 2010 - 2014.

\begin{tabular}{lccccc}
\hline \hline Year & 2010 & 2011 & 2012 & 2013 & 2014 \\
\hline Incubators & 1698 & - & 1421 & 1748 & 1704 \\
Large chicks & 261 & 360 & 482 & 578 & 163 \\
Island breeding success & $15.4 \%$ & - & $33.9 \%$ & $33.1 \%$ & $9.6 \%$ \\
\hline
\end{tabular}

Fig. 6. Estimates of island wide breeding success for the Tristan Albatross (Diomedea dabbenena) from 2001 - 2014 ( $\mathrm{n}=10$ years; total number of island wide incubating pairs ranged from 1271 - 2400; no data for years 2002, 2003, 2005, 2011) compared to the average breeding success for Diomedea spp. albatrosses (Tickell 2000).

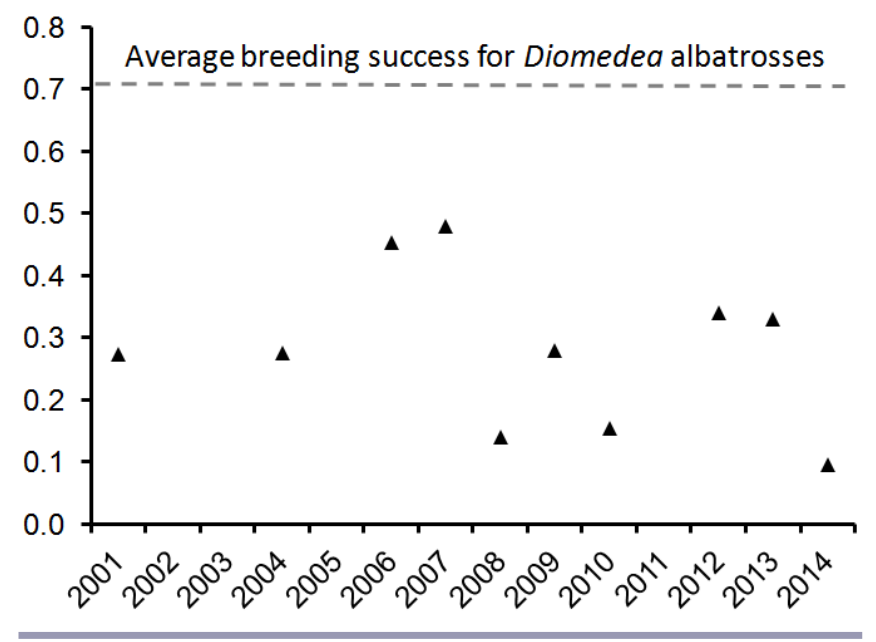

\section{DISCUSSION}

Despite albatross chicks being two orders of magnitude larger than house mice (Cuthbert and Hilton 2004, Wanless et al. 2007), mice were responsible for $93 \%$ (14/15) of Tristan Albatross chick failures in an area with higher than average breeding success monitored on Gough Island in 2014. Although mice were suspected of attacking Tristan Albatross chicks on Gough Island in 2001 (Cuthbert and Hilton 2004) and this was confirmed in 2004 (Wanless et al. 2007), ours are the first definite records of chicks being killed outright by mice. It was reasonably assumed that most chicks injured by mice were killed by Southern Giant Petrels and Brown Skuas because these birds are frequently observed feeding on freshly dead albatross chick carcasses (Verrill 1895, Wanless et al. 2009). However, of the six chick fatalities filmed, five died outright from their wounds and only one wounded chick was killed by an Southern Giant Petrel. This suggests that in most cases these birds scavenge chicks killed by mice. The actual cause of death appears to be a combination of physical injury and exhaustion from the absence of sleep and physical effort of being disturbed repeatedly by mice at night. Wounds observed on chicks elsewhere in the study colony closely resembled those seen in chicks filmed being attacked by mice. This fact, together with the presence of mouse wounds on chicks, strongly suggests that mice are largely responsible for the low breeding success of Tristan Albatrosses.

Our other significant finding was how quickly the process happens from the initial mouse attack to the death of the chick $(3.9 \pm 1.2$ days). This explains why relatively few injured chicks were recorded during monthly nest checks compared to the number of eventual failures. Most chicks simply disappeared between colony checks, with few clues as to the cause of death. Predation rates on albatross chicks peaked in May-June (Figs. 4 and 5), at the start of the austral winter, when mice turned to birds as an alternative food source. R. J. Cuthbert, R. M. Wanless, A. Angel, M.-H. Burlé, G. M. Hilton, H. Louw, P. Visser, J. Wilson, and P. G. Ryan (unpublished manuscript) found that mice in Tristan Albatross breeding areas showed an increase in mass and body condition over this same period.

Because mice are the only terrestrial mammal introduced to Gough Island, they occur at very high densities of up to 266 mice ha $^{-1}$ (R. J. Cuthbert, R. M. Wanless, A. Angel, M.-H. Burlé, G. M. Hilton, H. Louw, P. Visser, J. Wilson, and P. G. Ryan, unpublished manuscript). The lack of mammalian predators and competitors, together with the abundance of albatross and petrel chicks in winter, seemingly has encouraged the mice to adopt predatory behavior (R. J. Cuthbert, R. M. Wanless, A. Angel, M.H. Burlé, G. M. Hilton, H. Louw, P. Visser, J. Wilson, and P. G. Ryan, unpublished manuscript). It was noticeable that in 2014 virtually the only chicks to survive in areas of very high albatross mortality (e.g., West Point) were found at the highest elevations, suggesting that mouse attacks were worse in more mesic climates where mouse numbers may remain higher in winter. It has already been argued that global warming may further benefit mouse populations to the detriment of breeding seabirds (Huyser et al. 2000, Ferreira et al. 2006, Millien 2006, de Villiers and Cooper 2008).

Based on complete island counts of all incubating pairs and fledglings, the island wide breeding success of the Tristan Albatross since 2001 has been very low and averaged around $28 \%$; far lower than average breeding success for Diomedea spp. albatrosses elsewhere (Tickell 2000; Fig. 6). In addition, 2014 had the lowest breeding success yet recorded for both the whole island 
counts and the Gonydale study colony (Cuthbert et al. 2014). Although rodents and albatrosses coexist on other oceanic islands, the level of mouse predation we observed appears to occur only on Gough. Incidents of mouse-injured albatross have been reported from Marion Island (Jones and Ryan 2010) where peak mouse densities (237 mice ha ${ }^{-1}$ in mire habitats; McClelland 2013) are similar to those on Gough (266 mice ha ${ }^{-1}$, R. J. Cuthbert, R. M. Wanless, A. Angel, M.-H. Burlé, G. M. Hilton, H. Louw, P. Visser, J. Wilson, and P. G. Ryan, unpublished manuscript). However, the Wandering Albatross population on Marion is stable ( Nel et al. 2003, ACAP 2015) and incidents of mouse injured albatross chicks are rare (Jones and Ryan 2010, Dilley et al. 2013). By contrast, incidental sightings of mouse-injured Tristan Albatross chicks are common on Gough and mouse predation has an island-wide impact on chick production.

On Amsterdam Island, the breeding success of the critically endangered Amsterdam Albatross Diomedea amsterdamensis is low (61\%; Rivalan et al. 2010) relative to Wandering Albatross in the Indian Ocean (Weimerskirch et al. 1997). Thiebot et al. (2014) investigated the effect of introduced mammals (cats, rats Rattus spp., and mice) on brooded chicks by monitoring 12 nests with camera traps (25,000 photos over 2 months), but did not record any predation or interaction event and could not relate the rate of breeding success to chick predation.

\section{CONCLUSIONS}

The Tristan Albatross population cannot sustain current levels of chick mortality (Wanless et al. 2007, 2009); any further increase in mouse attacks will only accelerate the rate of population decrease. Fortunately it is possible to eradicate invasive rodents from islands (Clout and Veitch 2002, Angel et al. 2009). In the past, failure rates of mouse eradication attempts have generally been higher than for eradicating rats (Howald et al. 2007, Cuthbert et al. 2011), but the recent successful eradication of rabbits, rats, and mice from Macquarie Island $\left(\sim 128 \mathrm{~km}^{2}\right.$; Tasmania Parks and Wildlife Service 2014) is extremely encouraging given that Gough Island is about half the size ( 65 $\mathrm{km}^{2}$ ). A mouse eradication programme on Gough Island for the conservation of the Tristan Albatross and other vulnerable birds is a top conservation priority (Dawson et al. 2015).

Responses to this article can be read online at: http://www.ace-eco.org/issues/responses.php/738

\section{Acknowledgments:}

We thank Erica Sommer, Andrea Angel, Ross Wanless, Karen Bourgeois, Sylvain Dromzeé, Marie-Helene Burle, Ross Cowlin, Henk Louw, Paul Visser, Jeroen Lurling, Nic le Maitre, Graham Parker, Kalinka Rexer-Huber, Chris Bell, Mara Nydegger, Chris Jones, Michelle Risi, Werner Kuntz, the numerous South African meteorological staff volunteers for assistance in the field, and volunteers who assisted with the fledgling ground counts during the relief voyages. Thanks also to Rob Crawford and Bruce Dyer for the use of nest cameras; to the Tristan Conservation Department, and Tristan Island Council and Island Administrator for permission to undertake the work on Gough, and to Trevor Glass, George Swain, and Alex Mitham for their assistance in 2014. Susie Cunningham assisted with statistical analyses. Logistical and financial support was provided by the South African Department of Environmental Affairs, through the South African National Antarctic Programme (SANAP), the National Research Foundation, the University of Cape Town, and the Royal Society for the Protection of Birds ( RSPB). Long-term monitoring on Gough Island was established with a grant from the UK Foreign and Commonwealth Office with further support over the years from the UK Government's Overseas Territories Environment Programme (OTEP) and Darwin Initiative programme, the RSPB, and the Agreement on the Conservation of Albatrosses and Petrels. Comments from two anonymous reviewers were greatly appreciated and improved previous drafts.

\section{LITERATURE CITED}

Agreement on the Conservation of Albatrosses and Petrels (ACAP). 2015. Wandering Albatross Diomedea exulans. ACAP, Tasmania, Australia. http://www.acap.aq/en/acap-species/304wandering-albatross/file

Angel, A., R. M. Wanless, and J. Cooper. 2009. Review of impacts of the introduced house mouse on islands in the Southern Ocean: are mice equivalent to rats? Biological Invasions 11:1743-1754. http://dx.doi.org/10.1007/s10530-008-9401-4

Atkinson, I. A. E. 1985. The spread of commensal species of Rattus to oceanic islands and their effect on island avifaunas. Pages 35-81 in P. J. Moors, editor. Conservation of island birds. International Council for Bird Preservation, Technical Publication 3. Princeton University Press, Princeton, New Jersey, USA.

Bates, D., M. Machler, B. Bolker, and S. Walker. 2014. Fitting linear mixed-effects models using lme4. Cornell University, Ithaca, New York, USA. [online] URL: http://arxiv.org/abs/1406.5823

Clout, M. N., and C. R. Veitch. 2002. Turning the tide of biological invasion: the potential for eradicating invasive species. Pages 1-3 in M. N. Clout and C. R. Veitch, editors. Turning the tide: the eradication of invasive species. International Union for Conservation of Nature SSC Invasive Species Specialist Group, Gland, Switzerland and Cambridge, UK.

Croxall, J. P., S. H. M. Butchart, B. Lascelles, A. J. Stattersfield, B. Sullivan, A. Symes, and P. Taylor. 2012. Seabird conservation status, threats and priority actions: a global assessment. Bird Conservation International 22:1-34. http://dx.doi.org/10.1017/ S0959270912000020

Croxall, J. P., P. Rothery, S. P. C. Pickering, and P. A. Prince. 1990. Reproductive performance, recruitment and survival of Wandering Albatrosses Diomedea exulans at Bird Island, South Georgia. Journal of Animal Ecology 59:775-796. http://dx.doi. org/10.2307/4895

Cuthbert, R., and G. Hilton. 2004. Introduced house mice Mus musculus: a significant predator of threatened and endemic birds on Gough Island, South Atlantic Ocean? Biological Conservation 117:483-489. http://dx.doi.org/10.1016/j.biocon.2003.08.007

Cuthbert, R. J., J. Cooper, and P. G. Ryan. 2014. Population trends and breeding success of albatrosses and Giant Petrels at Gough 
Island in the face of at-sea and on-land threats. Antarctic Science 26:163-171. http://dx.doi.org/10.1017/S0954102013000424

Cuthbert, R. J., H. Louw, J. Lurling, G. Parker, K. Rexer-Huber, E. Sommer, P. Visser, and P. G. Ryan. 2013. Low burrow occupancy and breeding success of burrowing petrels at Gough Island: a consequence of mouse predation. Bird Conservation International 23:113-124. http://dx.doi.org/10.1017/S0959270912000494

Cuthbert, R. J., P. Visser, H. Louw, K. Rexer-Huber, G. Parker, and P. G. Ryan. 2011. Preparations for the eradication of mice from Gough Island: results of bait acceptance trials above ground and around cave systems. Pages 47-50 in C. R. Veitch, M. N. Clout, and D. R. Towns, editors. Island invasives: eradication and management. International Union for Conservation of Nature, Gland, Switzerland.

Dawson, J., S. Oppel, R. J. Cuthbert, N. Holmes, J. P. Bird, S. H. Butchart, D. R. Spatz, and B. Tershy. 2015. Prioritizing islands for the eradication of invasive vertebrates in the United Kingdom overseas territories. Conservation Biology 29:143-153. http://dx. doi.org/10.1111/cobi.12347

de Villiers, M. S., and J. Cooper. 2008. Conservation and management. Pages 301-324 in S. N. Chown and W. Froneman, editors. The Prince Edward Islands: land-sea interactions in a changing ecosystem. Sun Media, Stellenbosch, South Africa.

Dilley, B. J., D. Davies, M. Connan, J. Cooper, M. de Villiers, L. Swart, S. Vandenabeele, Y. Ropert-Coudert, and P. G. Ryan. 2013. Giant Petrels as predators of albatross chicks. Polar Biology 36:761-766. http://dx.doi.org/10.1007/s00300-013-1300-1

Elliott, H. F. I. 1953. The fauna of Tristan da Cunha. Oryx 2:41-53. http://dx.doi.org/10.1017/S0030605300035985

Ferreira, S. M., R. J. Van Aarde, and T. D. Wassenaar. 2006. Demographic responses of house mice to density and temperature on sub-Antarctic Marion Island. Polar Biology 30:83-94. http:// dx.doi.org/10.1007/s00300-006-0163-0

Howald, G., C. J. Donlan, J. P. Galván, J. C. Russell, J. Parkes, A. Samaniego, Y. Wang, D. Veitch, P. Genovesi, M. Pascal, A. Saunders, and B. Tershy. 2007. Invasive rodent eradication on islands. Conservation Biology 21:1258-1268. http://dx.doi. org/10.1111/j.1523-1739.2007.00755.x

Huyser, O., P. G. Ryan, and J. Cooper. 2000. Changes in population size, habitat use and breeding biology of Lesser Sheathbills (Chionis minor) at Marion Island: impacts of cats, mice and climate change? Biological Conservation 92:299-310. http://dx.doi.org/10.1016/S0006-3207(99)00096-8

International Union for Conservation of Nature (IUCN). 2014. Red List of Threatened Species. Version 2014.3: Species factsheet: Diomedea dabbenena Mathews, 1929. IUCN, Gland, Switzerland. [online] URL: http://www.iucnredlist.org/details/22728364/0

Jones, H. P., B. R. Tershy, E. S. Zavaleta, D. A. Croll, B. S. Keitt, M. E. Finkelstein, and G. R. Howald. 2008. Severity of the effects of invasive rats on seabirds: a global review. Conservation Biology 22:16-26. http://dx.doi.org/10.1111/j.1523-1739.2007.00859.x

Jones, M. G. W., and P. G. Ryan. 2010. Evidence of mouse attacks on albatross chicks on sub-Antarctic Marion Island. Antarctic Science 22:39-42. http://dx.doi.org/10.1017/S0954102009990459
Le Corre, M. 2008. Conservation biology: cats, rats and seabirds. Nature 451:134-135. http://dx.doi.org/10.1038/451134a

McClelland, G. T. 2013. Ecology of the Black-faced Sheathbill on Marion Island. Dissertation, Stellenbosch University, Stellenbosch, South Africa.

Medina, F. M., E. Bonnaud, E. Vidal, B. R. Tershy, E. S. Zavaleta, C. J. Donlan, B. S. Keitt, M. Le Corre, S. V. Horwath, and M. Nogales. 2011. A global review of the impacts of invasive cats on island endangered vertebrates. Global Change Biology 17:3503-3510. http://dx.doi.org/10.1111/j.1365-2486.2011.02464 $\mathrm{x}$

Millien, V. 2006. Morphological evolution is accelerated among island mammals. PLoS Biology 4(11):e384. http://dx.doi. org/10.1371/journal.pbio.0040321

Nel, D. C., F. Taylor, P. G. Ryan, and J. Cooper. 2003. Population dynamics of the Wandering Albatross Diomedea exulans at Marion Island: longline fishing and environmental influences. African Journal of Marine Science 25:503-517. http://dx.doi. org/10.2989/18142320309504039

Pannekoek, J., and A. J. van Strien. 2001. TRIM 3 manual. Trends and indices for monitoring data. Research paper 0102. Statistics Netherlands, CBS Voorburg, The Netherlands. [online] URL: http://www.ebcc.info/index.php?ID=13

R Core Team. 2014. $R$ : a language and environment for statistical computing. Version 3.1.2. $\mathrm{R}$ Foundation for Statistical Computing, Vienna, Austria.

Rivalan, P., C. Barbraud, P. Inchausti, and H. Weimerskirch. 2010. Combined impacts of longline fisheries and climate on the persistence of the Amsterdam Albatross Diomedia amsterdamensis. Ibis 152:6-18. http://dx.doi.org/10.1111/j.1474-919X.2009.00977. $\mathrm{x}$

Rowe-Rowe, D. T., and J. E. Crafford. 1992. Density, body size and reproduction of feral house mice on Gough Island. South African Journal of Zoology 27:1-5.

Ryan, P. G. 2005. Inaccessible island seabird monitoring manual. RSPB Research Report No. 16. Royal Society for the Protection of Birds, Sandy, UK.

Ryan, P. G., J. Cooper, and J. P. Glass. 2001. Population status, breeding biology and conservation of the Tristan Albatross Diomedea [exulans] dabbenena. Bird Conservation International 11:35-48. http://dx.doi.org/10.1017/S0959270901001058

Ryan, P. G., and R. J. Cuthbert. 2008. The biology and conservation status of the Gough Bunting Rowettia goughensis. Bulletin of the British Ornithologists' Club 128:242-253.

Schlaepfer, M. A., M. C. Runge, and P. W. Sherman. 2002. Ecological and evolutionary traps. Trends in Ecology and Evolution 17:474-480. http://dx.doi.org/10.1016/S0169-5347(02) 02580-6

Tasmania Parks and Wildlife Service. 2014. Macquarie Island pest eradication project. Tasmania Parks and Wildlife Service, Hobart, Tasmania, Australia. [online] URL: http://www.parks.tas.gov.au/ index.aspx? base $=12982$ 
Thiebot, J.-B., C. Barbraud, K. Delord, C. Marteau, and H. Weimerskirch. 2014. Do introduced mammals chronically impact the breeding success of the world's rarest albatross? Ornithological Science 13:41-46. http://dx.doi.org/10.2326/osj.13.41

Tickell, W. L. N. 2000. Albatrosses. Pica Press, Sussex, UK.

Verrill, G. E. 1895. On some birds and eggs collected by Mr Geo. Comer at Gough Island, Kerguelen Island and the island of South Georgia. Transactions of the Connecticut Academy of Arts and Sciences 9:430-478.

Wanless, R. M. 2007. Impacts of the introduced house mice on the seabirds of Gough Island. Dissertation, University of Cape Town, Cape Town, South Africa.

Wanless, R. M., A. Angel, R. J. Cuthbert, G. M. Hilton, and P. G. Ryan. 2007. Can predation by invasive mice drive seabird extinctions? Biology Letters 3:241-244. http://dx.doi.org/10.1098/ rsbl.2007.0120

Wanless, R. M., N. Ratcliffe, A. Angel, B. C. Bowie, K. Cita, G. M. Hilton, P. Kritzinger. P. G. Ryan, and M. Slabber. 2012. Predation of Atlantic Petrel chicks by house mice on Gough Island. Animal Conservation 15:472-479. http://dx.doi.org/10.1111/ j.1469-1795.2012.00534.x

Wanless, R. M., P. G. Ryan, R. Altwegg, A. Angel, J. Cooper, R. Cuthbert, and G. M. Hilton. 2009. From both sides: dire demographic consequences of carnivorous mice and longlining for the critically endangered Tristan Albatrosses on Gough Island. Biological Conservation 142:1710-1718. http://dx.doi. org/10.1016/j.biocon.2009.03.008

Weimerskirch, H. 1992. Reproductive effort in long-lived birds: age-specific patterns of condition, reproduction and survival in the Wandering Albatross. Oikos 64:464-473. http://dx.doi. org/10.2307/3545162

Weimerskirch, H., N. Brothers, and P. Jouventin. 1997. Population dynamics of Wandering Albatross Diomedea exulans and Amsterdam Albatross D. amsterdamensis in the Indian Ocean and their relationships with long-line fisheries: conservation implications. Biological Conservation 79:257-270. http://dx.doi. org/10.1016/S0006-3207(96)00084-5 